\title{
HIGH SENSITIVE TROPONIN I AND EXTENDED RANGE C-REACTIVE PROTEIN AS MARKERS TO PREDICT CARDIOTOXICITY IN LOCALLY ADVANCED BREAST CANCER WITH NEOADJUVANT CAF (CYCLOPHOSHPAMIDE, ADRIAMYCIN/ DOXORUBICIN, 5FLUOROURACIL) THERAPY
}

\author{
Yusfik Helmi Hidayat ${ }^{1}$, Hantoro Ishardyanto ${ }^{2}$, Leonita Anniwati ${ }^{3}$ \\ ${ }^{1}$ Surgery Program, Department of Surgery, ${ }^{2}$ Oncology Division, Department of Surgery, ${ }^{3}$ Department of Clinical \\ Pathology, Faculty of Medicine, Universitas Airlangga, Dr. Soetomo Hospital, Surabaya, Indonesia
}

\section{ABSTRACT}

The limitation of echocardiography to measure chemotherapy cardiotoxicity at left locally advanced breast cancer with large ulcer is still serious problem. HsTnI and erCRP are biomarkers to detect cardiotoxicity that are cheap, easy to examine and available at Dr.Soetomo Hospital Surabaya. This study was to compare HsTnI, erCRP and echocardiography as cardiotoxicity predictors in locally advanced breast cancer with neoadjuvant CAF therapy. This study used one-group pretest and posttest design among 23 locally advanced breast cancer patients. All patients underwent echocardiography, HsTnI, and erCRP examinations before and after 3 times chemotherapy and compared. The average age was 49.78 \pm 8.7 . Statistically significant decrease in LVEF was found after treatment $(67.98 \% \pm 4.06$ and $64.07 \% \pm 3.53, p=0.000)$. HsTnI was significantly increased after treatment $(0.007 \mu \mathrm{g} / \mathrm{mL} \pm 0.004$ and $0.043 \mu \mathrm{g} / \mathrm{mL} \pm 0.051 \mathrm{p}=0.000)$. erCRP was significantly decreased after treatment $(1.043 \mathrm{mg} / \mathrm{dL} \pm 0.913$ and $0.573 \mathrm{mg} / \mathrm{dL} \pm 0.444 \mathrm{p}=0.044)$. Decreased $L V E F$ and increased HsTnI was compared by its cardiotoxic cut-off. HsTnI was significantly better and faster to detect cardiotoxicity (0.033 $\pm 0.051 p=0.002)$. In conclusion, strong correlation is present in the detection of cardiotoxicity between HsTnI and LVEF. HsTnI is faster than echocardiography, and could be alternative diagnostic to detect early cardiotoxicity.

Keywords: Locally advanced breast cancer; doxorubicin; cardiotoxicity; LVEF; echocardiography; erCRP; HsTnI

\section{ABSTRAK}

Keterbatasan ekokardiografi dalam menilai kardiotoksisitas kemoterapi pada pasien kanker payudara kiri lanjut lokal dengan borok merupakan masalah serius. HsTnI dan erCRP adalah petanda biologis jantung yang murah, mudah dilakukan, dan tersedia di RS. Dr. Soetomo Surabaya. Penelitian ini bertujuan untuk membandingkan peningkatan kadar HsTnI dan erCRP dapat digunakan untuk memprediksi adanya efek kardiotoksik dini pemberian neoajuvan CAF pada penderita kanker payudara lanjut lokal. Penelitian ini menggunakan desain "one group pretest and posttest" pada 23 pasien kanker payudara lanjut lokal. Semua pasien menjalani pemeriksaan ekokardiografi, HsTnI, dan erCRP sebelum dan sesudah kemoterapi CAF 3 kali

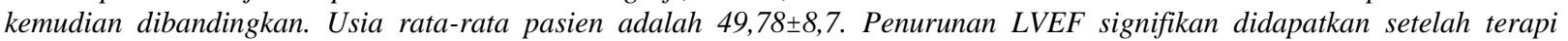
$(67,98 \% \pm 4,06$ dan 64,07\% $\pm 3,53, p=0,000)$. HsTnI meningkat secara signifikan setelah terapi $(0,007 \mu g / m L \pm 0,004$ dan 0,043

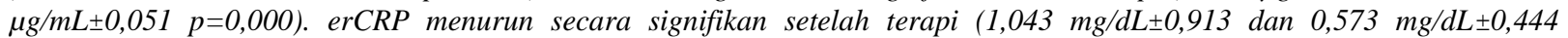
p=0,044). Penurunan LVEF dan peningkatan HsTnI dibandingkan berdasarkan cutoff kardiotoksiknya, HsTnI signifikan lebih baik dan cepat $(0,033 \pm 0,051$ p=0,002). Sebagai simpulan, Terdapat kesesuaian yang signifikan antara HsTnI dengan LVEF untuk menilai efek kardiotoksik. HsTnI lebih cepat dan dapat digunakan sebagai alternatif dalam mendeteksi dini kardiotoksisitas doksorubisin pada kemoterapi neoajuvan CAF.

Kata kunci: Kanker payudara lanjut lokal; doksorubisin; kardiotoksisitas; LVEF; ekokardiografi; erCRP; HsTnI

Correspondence: Yusfik Helmi Hidayat, Surgery Program, Department of Surgery, Faculty of Medicine, Universitas Airlangga, Dr. Soetomo Hospital, Surabaya, Jalan Prof dr Moestopo 6-8, Surabaya 60286, Indonesia. Email: yusfikhelmi@gmail.com

pISSN:2355-8393 • eISSN: 2599-056x • doi: http://dx.doi.org/10.20473/fmi.v56i2.21205

- Fol Med Indones. 2020;56:91-98 • Received 17 Jan $2018 \bullet$ Accepted 19 Jul 2018

- Open access under CC-BY-NC-SA license • Available at https://e-journal.unair.ac.id/FMI/ 


\section{INTRODUCTION}

Breast cancer is the leading cause of death after lung cancer. Data from National Cancer Institute in the USA 2016 showed 246,660 new cases $(14.6 \%$ of all new malignancies). In Dr Soetomo Hospital in 2009207 new patients were found in one year, $70 \%$ were in stage III and IV, about $30 \%$ were over 55 years old (Vetto et al 2009, Indonesian Ministry of Health 2015).

Management of locally advanced breast cancer is performed with neoadjuvant chemotherapy and mastectomy. Neoadjuvant chemotherapy is performed by administering CAF (Cyclophoshpamide, Adriamycin (Doxorubicin), 5FU). Doxorubicin alone has cardiotoxic side effects that can trigger left ventricular dysfunction that will decrease Left Ventricular Ejection Fraction (LVEF) and lead to heart failure (Shaikh et al 2013). LVEF measurement using echocardiography is a gold standard for evaluating cardiac abnormalities in patients who are planned to receive chemotherapy with cardiotoxic effects (Bovelli et al 2010, Plana et al 2014). This measurement has a weakness that it is less sensitive in detecting early changes in myocardial function. Another condition that complicates the use of this tool is the absence of echocardiography facilities in local hospitals, and echocardiography cannot be performed on left breast cancer with ulcers.

High Sensitive Troponin I (HsTnI) is the fourth generation of troponin levels examination that can detect plasma troponin levels ten times lower than ordinary troponin levels (Reagan et al 2008). Research by Onitilo et al (2012) found that High sensitive CReactive Protein (Hs-CRP) can be used as early detection of cardiotoxicity due to transtuzumab chemotherapy. HsTnI and CRP, especially erCRP, are expected to have benefit in early detection of cardiotoxicity in patients receiving doxorubicin chemotherapy and are expected to be alternative examination if echocardiography could not be performed. In addition to having lower cost than echocardiography, HsTnI and erCRP examinations are easy to do only by blood collection, and can be done at Dr. Soetomo Hospital Surabaya.

\section{MATERIALS AND METHODS}

This study was an analytic observational study using one group pretest and posttest design. The study was conducted at the Center of Cancer Care and
Development and Service, Dr. Soetomo Hospital, Surabaya. This study was conducted in AugustNovember 2017. The samples were local breast cancer patients who received CAF chemotherapy who visited to the Center for Cancer Care and Development, Dr Soetomo Hospital, Surabaya, and fulfilled the inclusion criteria and did not have exclusion criteria.

Qualified patients were examined with echocardiography and blood sampling was taken to measure prechemotherapy HsTnI and erCRP levels. Then, CAF chemotherapy was done up to a cumulative dose of doxorubicin $=150 \mathrm{mg} / \mathrm{m} 2$ (3rd cycles). Postchemotherapy echocardiography and blood sampling tests were performed to measure HsTnI and erCRP levels following the 3rd cycles of CAF chemotherapy. HsTnI level was measured with immunoassay using ADVIA Centaur Analyzer with cut-off level $=0.02$ $\mu \mathrm{g} / \mathrm{mL}$ and erCRP was measured with Particle Enhanced Turbidimetric Immunoassay using Dimension Analyzer with cut-off level $=0.33 \mathrm{mg} / \mathrm{dL}$.

\section{RESULTS}

The subjects in this study had several characteristic variables consisting of age, breast cancer site, histopathology type, and echocardiography results before and after chemotherapy. These characteristics are listed in Table 1.

Most subjects were in the 40-50 years group (39.13\%). The youngest age of the subjects was 33 years old and the oldest was 67 years old. Subject grouping was based on histopathology type of breast cancer and breast cancer site. IDC (Infiltrating Ductal Carcinoma) breast cancer had a higher percentage than ILC (Infiltrating Lobular Carcinoma) types. The location of breast cancer lesions in the subjects tended to be similar between the right and left breast with a ratio of $52.17 \%$ in the right breast and $47.83 \%$ in the left breast.

Fig. 1 shows that the percentage of difference in the sample population increases with diastolic dysfunction between before treatment $(18 \%)$ and after treatment $(61 \%)$. There was also a difference in the percentage of normal echocardiographic results of the patients before and after treatment, ie $65 \%$ before treatment and 30\% after treatment. There were also 4 patients with ulcerative left breast cancer that resulted in the limitations of echocardioographic assessment (poor echo window). 
Table 1. Frequency data of research subjects

\begin{tabular}{|c|c|c|c|}
\hline Variables & Categories & Total & $\%$ \\
\hline \multirow[t]{4}{*}{ Age } & $30-40$ years & 3 & 13.04 \\
\hline & $40-50$ years & 9 & 39.13 \\
\hline & $50-60$ years & 8 & 34.78 \\
\hline & $>60$ years & 3 & 13.04 \\
\hline \multirow[t]{2}{*}{ Location } & Right & 12 & 52.17 \\
\hline & Left & 11 & 47.83 \\
\hline \multirow[t]{2}{*}{ Histopathology } & IDC & 22 & 95.65 \\
\hline & ILC & 1 & 4.35 \\
\hline Echocardiography & Diastolic Disfunction & 4 & 17.4 \\
\hline \multirow[t]{3}{*}{ before CAF Therapy } & LVH Concentric & 4 & 17.4 \\
\hline & Normal Echo + normal window & 11 & 47.83 \\
\hline & Normal Echo + Poor window & 4 & 17.4 \\
\hline Echocardiography after & Diastolic Disfunction & 14 & 60.9 \\
\hline \multirow[t]{3}{*}{3 cycles CAF Therapy } & LVH Concentric & 2 & 8.7 \\
\hline & Normal Echo + normal window & 3 & 13.04 \\
\hline & Normal Echo + Poor window & 4 & 17.4 \\
\hline
\end{tabular}

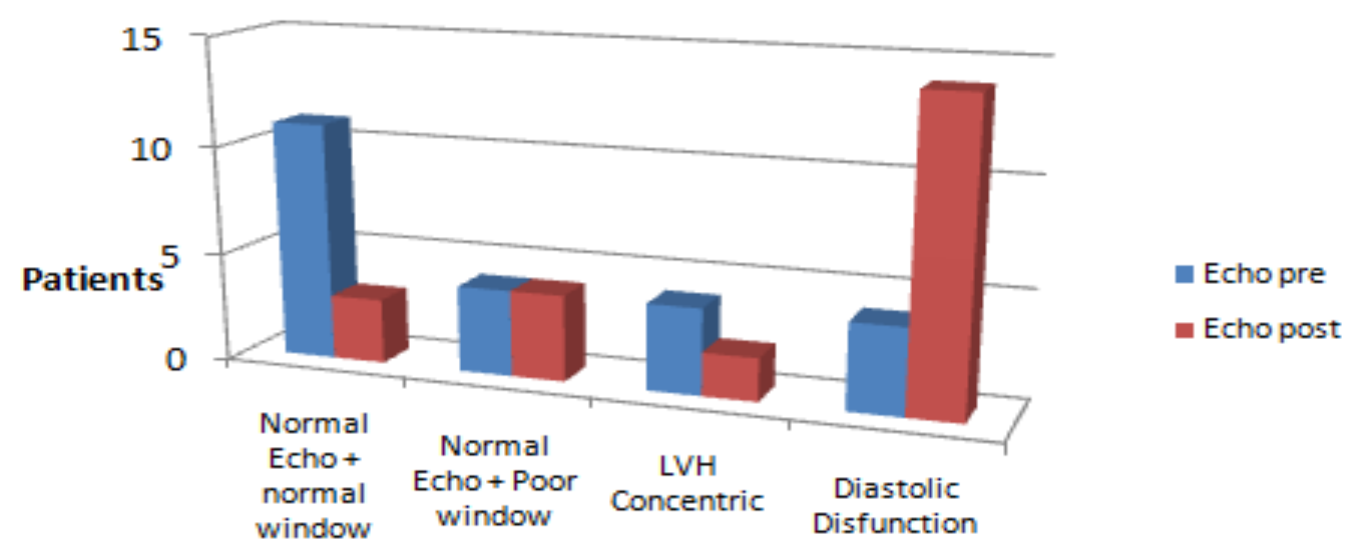

Fig. 1. Description of changes in echocardiographic results before and after 3-cycle CAF chemotherapy.

Table 2. Normality and difference test results of echocardiography, erCRP and HsTnI before and after neoadjuvant 3cycle CAF chemotherapy

\begin{tabular}{lccccc}
\hline \multicolumn{1}{c}{ Variables } & Mean & Total & $\begin{array}{c}\text { Standard } \\
\text { deviation }\end{array}$ & $\begin{array}{c}\text { Normality test } \\
\text { significance }\end{array}$ & Significance \\
\hline EF.Echo.Pre & 67.97 & 23 & 4.05 & 0.32 & 0.00 \\
EF.Echo.Post & 64.07 & 23 & 3.52 & 0.18 & 0.04 \\
\hline CRP Pre & 1.043 & 23 & 0.913 & 0.01 & 0.00 \\
CRP Post & 0.573 & 23 & 0.444 & 0.00 & \\
\hline HsTnI Pre & 0.007 & 23 & 0.004 & 0.00 & 0.00 \\
HsTnI Post & 0.043 & 23 & 0.051 & &
\end{tabular}

EF: Paired T-Test

CRP: Wilcoxon Signed-Ranks Test

HsTn1: Wilcoxon Signed-Ranks Test 


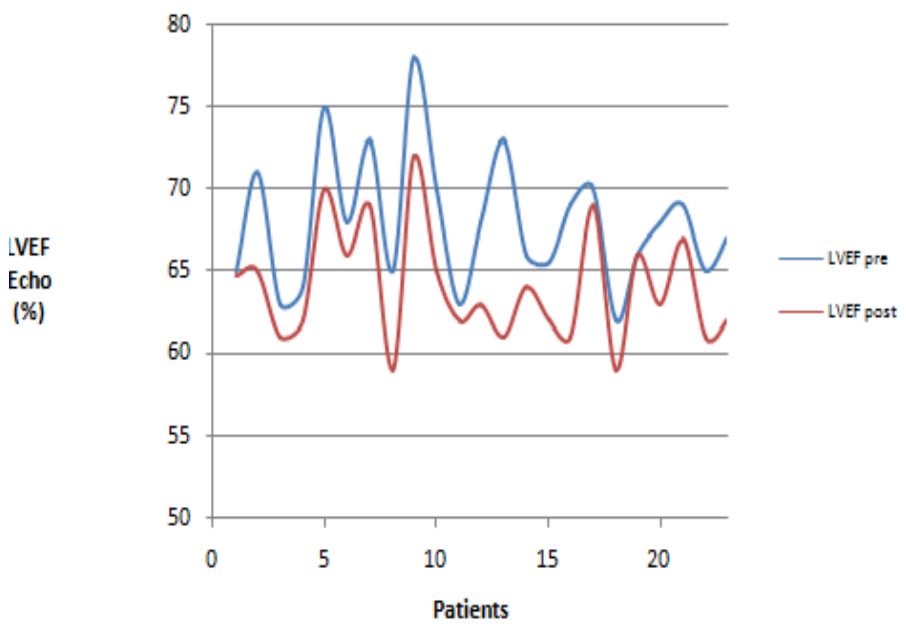

Fig. 2. LVEF echocardiography values before and after 3-cycle CAF chemotherapy.

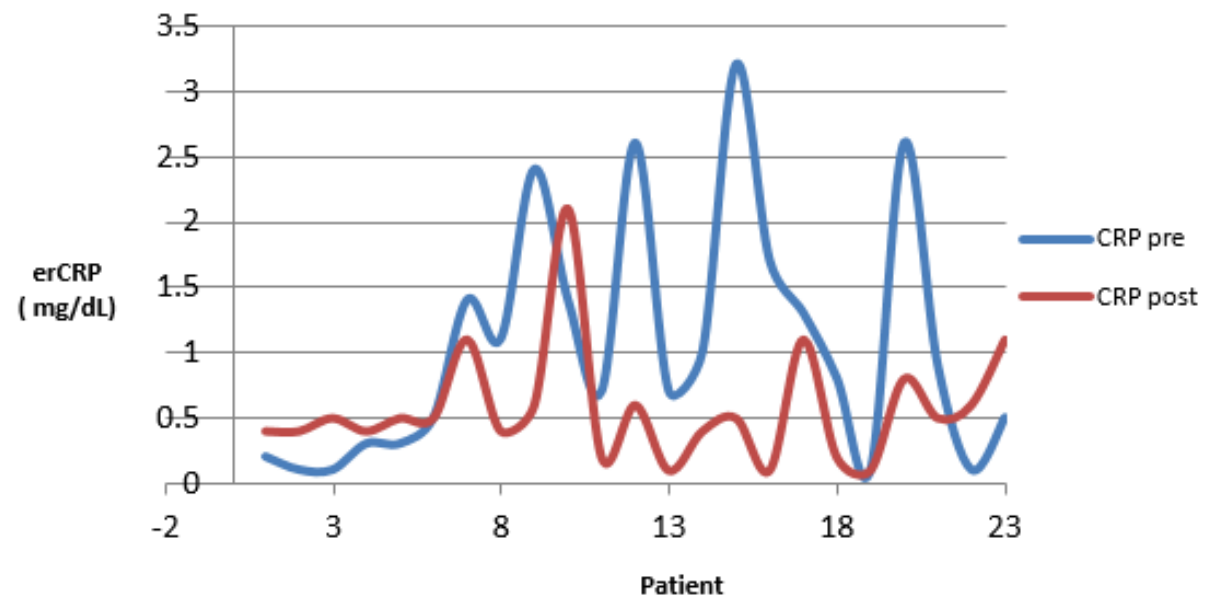

Fig. 3. erCRP values before and after 3-cycle CAF chemotherapy.

The youngest age of the subjects was 33 years old and the oldest 67 years old with average age of the subjects was 49.78 years (standard deviation: 8.71). In statistics, the body surface area shows less than $10 \%$. This illustrates that the study subjects had similar anthropometric tendencies with each other/no diversity. This affected the doses of chemotherapy drug delivery among study subjects that tended to be the same because the determination of chemotherapy drug doses was given based on body surface area of the patient.

There were significant differences between LVEF values before and after treatment in this study subjects
$(67.98 \% \pm 4.06$ and $64.07 \% \pm 3.53, \mathrm{p}=0.000)$ (Table 2). Figure 2 shows LVEF impairment on echocardiographic examination after treatment when compared to before treatment (mean LVEF before treatment $=67.98$, $\mathrm{SD}=4.06$; mean LVEF after treatment=64.07, $\mathrm{SD}=3.53$ ).

There were significant differences in erCRP values before and after treatment $(1.043 \mathrm{mg} / \mathrm{dL} \pm 0.913$ and $0.573 \mathrm{mg} / \mathrm{dL} \pm 0.444 \mathrm{p}=0.044$ ). Figure 3 shows changes in erCRP values before and after chemotherapy. However, this is in contrast to the hypothesis in this study that after chemotherapy there will be an increase in erCRP values. 


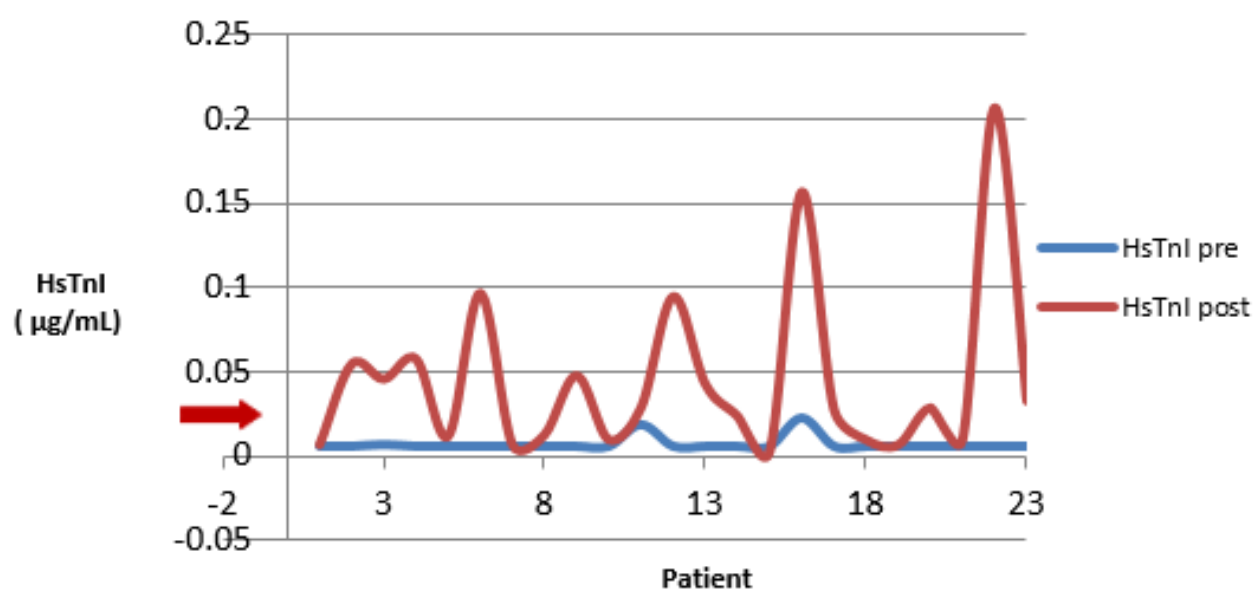

Fig. 4. HsTnI values before and after 3-cycle CAF chemotherapy.

Table 3. Comparative test in HsTnI, and LVEF levels

\begin{tabular}{ccccccc}
\hline \multirow{2}{*}{ Variables } & \multicolumn{2}{c}{ Categories } & \multirow{2}{*}{ Mean } & Standard & \multirow{2}{*}{ Significance } \\
\cline { 2 - 3 } & Positive & Neviation & & \\
\hline erCRP changes & $5(21.7 \%)$ & $18(78.3 \%)$ & & -0.469 & 0.924 & 0.002 \\
HsTnI changes & $12(52.2 \%)$ & $11(47.8 \%)$ & & 0.033 & 0.051 & \\
LVEF changes & $2(8.7 \%)$ & $21(91.3 \%)$ & & -3.903 & 2.745 & \\
\hline
\end{tabular}

Cut-off CRP: $>0.33 \mathrm{mg} / \mathrm{dL}$

Cut-off HsTn $1: \geq 0.02 \mu \mathrm{g} / \mathrm{mL}$

Cut-off LVEF: $<55 \%$ or changes $>10 \%$

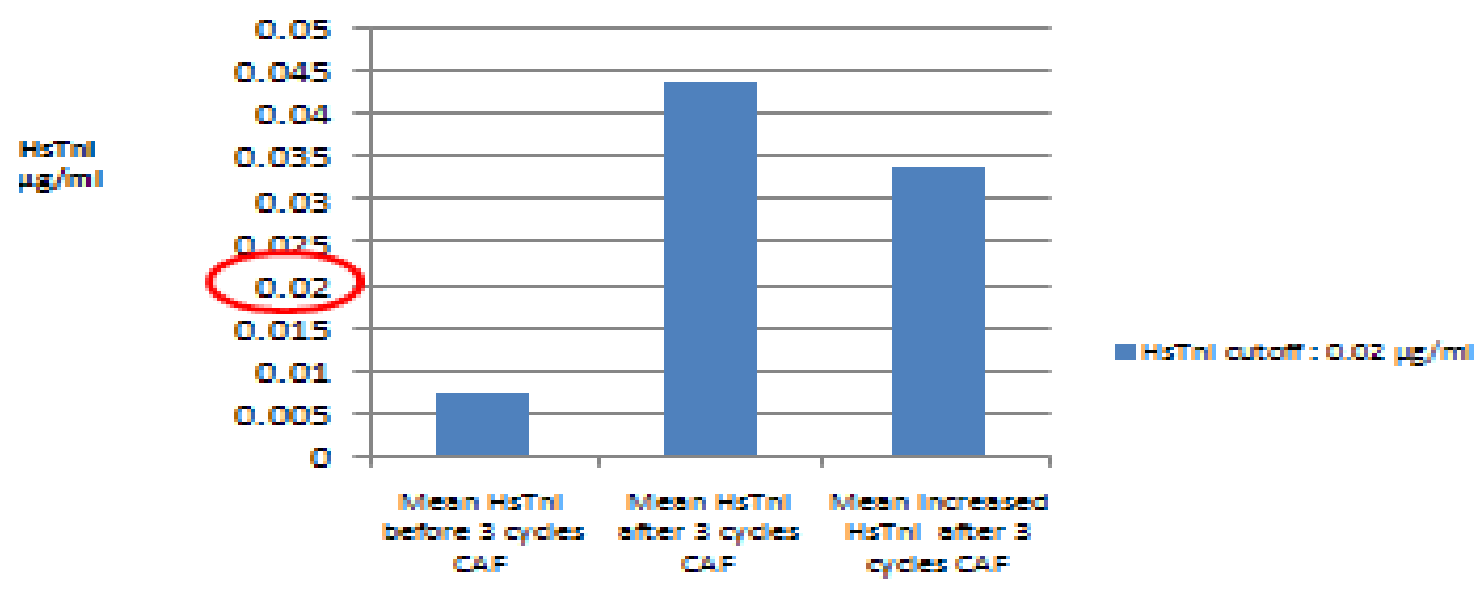

Fig. 5. Mean HsTnI level changes.

In data analysis, the difference of HsTnI increase showed that there was significant difference of HsTnI value before and after treatment $(0.007 \mu \mathrm{g} / \mathrm{mL} \pm 0.004$ and $0.043 \mu \mathrm{g} / \mathrm{mL} \pm 0.051 \mathrm{p}=0.000)$. HsTnI values before and after 3-cycle CAF chemotherapy are shown in Figure 4. The authors also linked changes in LVEF screening variables and changes in HsTnI examinations in the study subjects to compare the better variables in describing heart damage during neoadjuvant chemotherapy as can be seen in Table 3 .

Concluded from the data, HsTnI increase that corresponded to the cut-off was found in 12 patients (52.2\%), followed by LVEF reduction in echocardio- 
graphy according to cut-off in 2 patients $(8.7 \%)$. This explains that HsTnI is better than echocardiography in early cardiotoxic detection with significant level $(0.033$ $\pm 0.051 \mathrm{p}=0.002)$. Although erCRP changes was decreased there were 5 patients $(21.7 \%)$ with erCRP level is higher than its cut-off.

Cut-off HsTnI assessment in this study can be seen in Figure 5 which shows the mean value of HsTnI before chemotherapy of 0.007 ( $\mathrm{SD}=0.043)$, after 3-cycle $\mathrm{CAF}$ of $0.043(\mathrm{SD}=0.051)$ and mean HsTnI increased after 3cycle CAF chemotherapy as much as 0.033 with $(\mathrm{SD}=0.051)$.

Based on diagnostic performance of HsTnI measuring cardiotoxic the results are sensitivity test $100 \%$ and spesificity test $52.4 \%$. Positive Predictive Value > 2 snd Negative Predictive Value : 0 shows that HsTnI is a good diagnostic examination and could be an alternative diagnostic if echocardiography could not be performed.

\section{DISCUSSION}

The subjects obtained the highest group in the age range 40-50 years $(39.13 \%)$, supported the literature review by Pasaribu et al who get the average age of locally advanced breast cancer was 48.64 years $\pm 7,787$. IDC (Infiltrating Ductal Carcinoma) breast cancer has a higher percentage of $95.65 \%$, according to research by Pasaribu et al. which showed that, histopathologically, $75 \%$ of breast cancer is of IDC type (Suyatno \& Pasaribu 2010). Comparison of echocardiography results before and after 3-cycle CAF chemotherapy showed normal echocardiographic results before treatment of $65.2 \%$ and after treatment of $30.4 \%$. A prospective study by Lisi et al (2014) showed that in breast cancer patients receiving anthracycline chemo- therapy, cardiac systolic and diastolic function have decreased immediately after the onset of chemotherapy. CHF may occur after cumulative dosage of doxorubicin $550 \mathrm{mg} / \mathrm{m} 2$ or more (Torres et al 2012, Pizzino et al 2014, Lisi et al 2014). Studies by Ismail mention that the emergence of cardiotoxic effects of doxorubicin, which is characterized by decreased LVEF, occurs in cumulative doses of $>300 \mathrm{mg} / \mathrm{m} 2$. However, the study found a decrease in LVEF at a cumulative dose of 150 $\mathrm{mg} / \mathrm{m} 2$ (Limat et al 2003).

This study showed no correlation between cardiotoxicity and erCRP values. This is consistent with Ky's (2014) study stating that erCRP levels have no significant association with post-chemotherapy cardiotoxicity. The decrease of erCRP level in this study can be attributed to Nonsteroidal Anti-Inflammatory Drugs (NSAIDs), platelet inhibitors, statin drugs, Angiotensin Converting Enzyme Inhibitors (ACE Inhibitors) and antioxidants (Ky 2014).

HsTnI values increased significantly before and after 3cycle chemotherapy, which corresponds with Sawaya's (2009) study on early detection and prediction of cardiotoxicity in chemotherapy-treated patients. Another study by Herman et al. in rats treated with doxorubicin for 2 to 12 weeks found elevated levels of troponin and therefore it could be used as an instrument to assess early cardiotoxicity due to doxorubicin.

Comparison of changes in Increased HsTnI and Decreased LVEF before and after 3- cycles chemotherapy with each cut-off using McNemar test showed significant difference $\mathrm{p}=0.002(\mathrm{p}<0.05)$. HsTnI is better and faster than echocardiography examination to early detect the onset of heart damage during neoadjuvant chemotherapy with $\mathrm{CAF}$ in locally advanced breast cancer.

Table 4. Diagnostic performance HsTnI measuring cardiotoxic

\begin{tabular}{|c|c|c|c|c|c|c|}
\hline \multirow[t]{2}{*}{ Examination } & & \multicolumn{2}{|c|}{$\begin{array}{c}\text { LVEF } \\
\text { Echocardiography }\end{array}$} & \multirow[t]{2}{*}{ Total } & \multirow[t]{2}{*}{ Test } & \multirow[t]{2}{*}{ Results } \\
\hline & & Positive & Negative & & & \\
\hline \multirow{6}{*}{ HsTnI } & Positive & $2^{\mathrm{a}}$ & $10^{\mathrm{b}}$ & 12 & Sensitivity & $100 \%$ \\
\hline & & & & & Spesificity & $52.4 \%$ \\
\hline & & & & & Positive Prediction Value & $16.7 \%$ \\
\hline & Negative & $0^{\mathrm{c}}$ & $11^{\mathrm{d}}$ & 11 & Negative Prediction Value & $100 \%$ \\
\hline & & & & & Accuration & $56.5 \%$ \\
\hline & & & & & Likehood Ratio Positive & $2.1 \%$ \\
\hline Total & & 2 & 21 & 23 & Likehood Ratio Negative & $0 \%$ \\
\hline
\end{tabular}


HsTnI level cut-off causing cardiotoxic effects in this study was as much as $0.043 \pm 0.051 \mu \mathrm{g} / \mathrm{mL}$ or, if obtained increase in HsTnI levels, of $0.033 \pm 0.051$ from the original level. Feola et al (2011) and Garrone et al (2012) stated that the cut-off value of HsTnI that has a cardiotoxic effect is $0.03 \mu \mathrm{g} / \mathrm{mL}$. Local advanced breast cancer patients receiving CAF chemotherapy with HsTnI results between 0.020 to $<0.043 \mu \mathrm{g} / \mathrm{mL}$ need to have adjustment of chemotherapy doses. If we obtain HsTnI results after chemotherapy of $>0.043 \mu \mathrm{g} / \mathrm{mL}$, it is recommended to replace the chemotherapy regimen with the one that has more minimal cardiotoxic effect (Garrone et al 2012).

\section{CONCLUSION}

HsTnI levels increases and erCRP levels decreases significantly before and after neoadjuvant 3-cycle CAF chemotherapy. erCRP capacity is not appropriate in monitoring cardiotoxic effects of doxorubicin, in which changes in erCRP levels before and after neoadjuvant 3cycle chemotherapy showed a decrease. In this case, erCRP can not be used to monitor cardiotoxic effects of doxorubicin.

There is a significant appropriateness and difference in ability between HsTnI and echocardiography to monitor cardiotoxic effects of doxorubicin. HsTnI can be used as an alternative modality to detect the effect of doxorubicin cardiotoxicity if echocardiography could not be performed. HsTnI is also faster in detecting the presence of cardiotoxic chemotherapy effects of doxorubicin so that it can be used for early detection of cardiotoxicity with sensitivity $100 \%$ and specificity $52.4 \%$

\section{REFERENCES}

Bovelli D, Plataniotis G, Roila F (2010). Cardiotoxicity of chemotherapeutic agents and radiotherapy-related heart disease: ESMO Clinical Practice Guidelines. Annals of Oncology 21, 277-282

Feola M, Garrone O, Occelli M, Francini A, Biggi A, Visconti G, et al (2011). Cardiotoxicity after anthracycline chemotherapy in breast carcinoma: effects on left ventricular ejection fraction, troponin I and brain natriuretic peptide. Int J Cardiol 148, 194 810. DOI: 1016/j.ijcard.2009.09.564

Garrone O, Crosetto N, Lo Nigro C, Catzeddu T, Vivenza D, Monteverde M, et al (2012). Prediction of anthracycline cardiotoxicity after chemotherapy by biomarkers kinetic analysis. Cardiovasc Toxicol 12, 135-4210. DOI: 1007/s12012-011-9149-4
Ky B (2014). Early increases in multiple biomarkers predict subsequent cardiotoxicity in patients with breast cancer treated with doxorubicin, taxanes and tratuzumab. Journal of the American College of Cardiology 63, 809-816

Limat S, Demesmay K, Voillat L, Bernard Y, Deconinck E, Brion A (2003). Early cardiotoxicity of the CHOP regimen in aggressive non-Hodgkin's lymphoma. Annals of Oncology 14, 277-281

Lisi DD, Leggio G, Vitale G, Arrotti S, Iacona R, Inciardi RM, Nobile D, Bonura F, Novo G, Russo A, Novo S (2014). Chemotherapy cardiotoxicity: cardioprotective drugs and early identification of cardiac dysfunction. J Cardiovasc Med 16, 1-5

Onitilo AA, Engel JM, Liang H, et al (2012). Highsensitive C-reactive protein (Hs-CRP) as a biomarker for trastuzumab-induced cardiotoxicity in HER2positive early-stage breast cancer: a pilot study. Breast Cancer Res Treat 134, 291-298

Pizzino F, Vizzari G, Bomzer CA, Qamar R, Carerj S, Zito C, Khandheria BK (2014). Diagnosis of chemotherapy-induced cardiotoxicity. Journal of Patient-Centered Research and Reviews 1, 120-127

Plana JC, Barac A, Ewer MS, Ky B, Scherrer-Crosbie M, Ganame J, Sebag IA, Agler DA, Badano LP, Banchs J, Cardinale D, Carver J, Cerqueira M, Decara JM, Edvardsen T, Flamm SD, Force T, Griffin BP, Jerusalem G, Liu JE, Magalhaes A, Marwick T, Sanchez LY, Sicari R, Villarraga HR, Lancellotti P (2014). Expert consensus for multimodality imaging evaluation of adult patients during and after cancer therapy: a report from the American Society of Echocardiography and the European Association of Cardiovascular Imaging. European Heart Journal Cardiovascular Imaging 15, 1063-1093

Pusat Data dan Informasi Kementerian Kesehatan Indonesia. Data Epidemiologi Kanker Indonesia. 2015. Available at http://www.depkes.go.id/resources/ download/pusdatin/infodatin/infodatin-kanker.pdf. Accessed October 19, 2016

Reagan, Dolci A, Dominici R, Cardinale D, Sandri MT, Panteghini M (2008). Biochemical markers for prediction of chemotherapy-induced cardiotoxicity. Am J Clin Pathol 130, 688-695

Sawaya H (2012). American Heart Association: Assesment of echocardiography and viomarkers for the extended prediction in patients treated with antracyclines, taxanes, and trastuzumab. Boston, USA

Shaikh AS, Saleem AF, Mohsin SS, Alam MM, Ahmed MA (2013). Anthracycline-induced cardiotoxicity: prospective cohort study from Pakistan. BMJ Open 3, $1-6$

Suyatno, Pasaribu ET (2010). Bedah onkologi diagnostik dan terapi 1st Ed. Jakarta, Sagung Seto

Torres VM, Simic VD (2012). Doxorubicin-induced oxidative injury of cardiomyocytes - Do we have right 
strategies for prevention? In: Fiuza M (ed). Cardiotoxicity of Oncologic Treatment. Croatia, InTech, p 277-282
Vetto JT, Luoh SH, Naik A (2009). Breast cancer in premenoupausal women Curr Probl Surg 46, 9441004 